\title{
OVERLAPPING REMEDIES AND THE UNEXPECTED TERMINATION OF OIL AND GAS LEASES
}

\author{
DAVID R PERCY, QC AND DAVID MCGILLIVRAY*
}

The freehold oil and gas lease in Canada has had a perilous and uncertain existence. In the early cases, the courts applied a literal interpretation of the leases, resulting in numerous unexpectedly terminated leases. In recent years, there has been a resurgence of cases involving terminated leases. Modern case law recognizes that the failure of a lease can create liabilities in both tort and restitution, but courts have faced difficulties in dealing with the overlapping compensatory and restitutionary remedies. The modern case law has been heavily criticized, but the authors argue that there is a smaller difference between the overlapping remedies than is commonly supposed when the underlying purpose of restitutionary remedies is examined, and they propose a resolution to the problem of overlapping remedies.
L'existence du bail franc pour le pétrole et le gaz au Canada est périlleuse et incertaine. Dans les premières causes, les tribunaux utilisaient une interprétation littérale du bail ce qui résultait en de nombreuses résiliations inattendues de baux. Au cours des dernières années, les causes impliquant des résiliations de bail apparaissent de nouveau. La jurisprudence moderne reconnaît que la résiliation d'un bail peut amener des responsabilités à la fois en matière de délit et de restitution, mais les redressements compensatoires et de restitution qui se chevauchent ont causé des difficultés pour les tribunaux. La jurisprudence moderne a fait l'objet d'une forte critique, mais les auteurs font valoir qu'il y a une petite différence entre le chevauchement de mesures couramment imposées lorsqu'on examine la cause sous-jacente des redressements fondés sur la restitution, et ils suggèrent un règlement au problème de ce chevauchement.

\section{TABLE OF CONTENTS}

I. INTRODUCTION . . . . . . . . . . . . . . . . . . . . . . . 252

A. FAILURe to DRILl or PAy Delay RENTAL . . . . . . . . . 253

B. Operations AT THE END of the PRimARY TERM . . . . . . . . . . 253

C. The Pooling Clause . . . . . . . . . . . . . . . . . . . . . . . 254

D. The Shut-In Well Provision . . . . . . . . . . . . . . . . . . . . . 254

E. PRODUCTION DURING THE EXTENDED

TERM OF THE LEASE . . . . . . . . . . . . . . . . . . . . . . 255

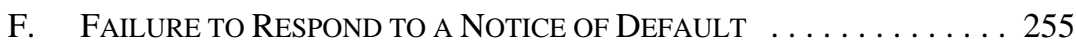

II. The First Phase Of LeAse Failure Cases . . . . . . . . . . . . . . . . . 256

A. Failed Leases Where No Production Occurred . . . . . . . . . 257

B. Failed Leases That Achieve Production . . . . . . . . . . . 258

III. LEASE FAILURE IN THE NEW MiLlenNiUM $\ldots \ldots \ldots \ldots \ldots \ldots \ldots$

A. THE COMPENSATORY APPROACH $\ldots \ldots \ldots \ldots . \ldots . \ldots . \ldots . \ldots 263$

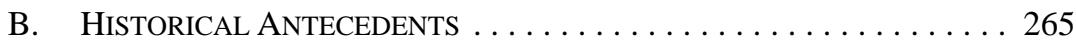

C. THE EXTENSION OF THE COMPENSATORY APPROACH $\ldots \ldots \ldots \ldots 266$

IV. A PRINCIPLED APPROACH TO OVERLAPPING REMEDIES . . . . . . . . . . . . . 268

David R Percy, QC holds the Borden Ladner Gervais Chair in Energy Law and Policy at the Faculty of Law, University of Alberta. David McGillivray is an Associate in the Calgary office of Fraser Milner Casgrain LLP. David Percy wishes to acknowledge the great insights he gained from conversations with James Edelman, then Professor of the Law of Obligations at Keble College, Oxford, now Justice of the Supreme Court of Western Australia, and the assistance received from John Lowe, George W Hutchison Professor of Energy Law at the Dedman School of Law at Southern Methodist University. He is also indebted to Kimberly Precht, holder of a Roger S Smith Research Award at the University of Alberta, for her valuable assistance. He adds that they bear no responsibility for the views expressed in the article and any errors should be attributed to the authors. 


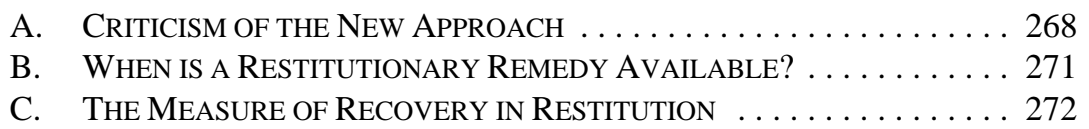

\section{INTRODUCTION}

The freehold oil and gas lease in Canada has had a perilous and uncertain existence. Cases going back as far as the early 1960s have demonstrated the ease with which the freehold lease may come to a sudden and unexpected end. There have been two distinct phases in the development of the jurisprudence over this time. The first phase of cases involving failed leases spanned the decade that stretched from 1961 to 1971. The cases were marked by a "determinedly literalist application" of the words of the lease, often by the Supreme Court of Canada, in a manner which "frequently astounded those who originally prepared the document." Although a member of the Supreme Court of Canada, in one case of literal interpretation, observed that he was not satisfied that "the result accords with the intention of the parties to the instrument,"2 this approach left the legal landscape littered with unexpectedly terminated leases. The cases in the first phase of Canadian law were also notable for devoting very little attention to the remedial consequences of unexpected failure.

After 1971, there was a period of relative quiescence when few cases involving challenges to leases reached the courts. It appeared that most of the obvious causes of failure had been covered by improvements in drafting, so that new leases were not often the subject of litigation. However, the oil and gas lease can be long-lived, and many of the older leases continued in existence with hidden pitfalls that would only be exposed in the event of a challenge.

There has been a resurgence in cases of lease failure in the past decade. Anecdotally it has been suggested that a rash of new actions have mounted challenges against existing leases but they have not yet reached the courts. This second phase of Canadian case law is no longer marked by a tendency towards literal interpretation, but it has exposed new areas in which leases can be vulnerable. In addition, the modern case law has placed an intense focus on the remedies available to both parties following the failure of lease.

The purpose of this article is primarily to deal with the remedial consequences of the failure of leases where the production of petroleum or natural gas has occurred after the termination of the lease. It will focus on four major issues:

(1) A comparison of the different approaches to remedies in the first and second phases of Canadian case law;

(2) The recognition in recent cases that the failure of a lease can create liabilities in both tort and restitution, and the difficulties that courts have experienced in dealing 
with the overlap between these areas of law and their respective approaches to the assessment of damages;

(3) An examination of the severe criticism of decisions in recent cases that awarded a compensatory remedy in tort where leases have failed and that dismissed remedies in restitution on the grounds that they would create a windfall to the lessor;

(4) A resolution of the important issue of how restitution and tortious remedies relate to each other, and the quantification of damages under each approach.

In order to provide some context for the discussion of remedies, we will briefly review in turn the six general areas which have proved vulnerable in freehold oil and gas leases. The first three areas of vulnerability were prominent in the first phase of the development of Canadian law, while recent cases have involved the last three areas.

\section{A. FAilure To DRILl OR PAy Delay RENTAL}

Traditional oil and gas leases often contained a provision that provided for the automatic termination of the lease if the lessee did not commence operations for the drilling of a well within one year from the date of the lease. The requirement to drill a well could typically be deferred if the lessee paid the required delay rental on or before the anniversary date of the lease. Leases frequently failed because the lessee did not commence drilling operations and did not pay the delay rental in accordance with the requirements of the lease. ${ }^{3}$

\section{B. Operations at The End OF THE Primary Term}

The final year of the primary term of a lease is particularly hazardous for a lessee. The lessee no longer has the option of paying a delay rental at the end of the final year, and many leases only allowed the lease to be extended if the lessee achieved production before the end of the primary term. In the first phase of the development of Canadian law, three cases involved the production of oil and gas after the lease had terminated because the lessee failed to bring a well into production within the primary term. They resulted from the classic interpretation of a common variety of the freehold lease first adopted in the Canada-Cities Service Petroleum Corp v Kininmonth decision, ${ }^{4}$ in which termination occurred when the lessee commenced a well within the primary term but achieved production only after its expiry. The cases concluded that this type of lease expired at the end of the primary term unless a well was in production at that time. 


\section{The Pooling Clause}

In order to maximize the production of oil and gas, Alberta was quick to enact conservation legislation that limited the density of wells to one for each drilling spacing unit. The normal drilling spacing unit was set at a quarter section for an oil well and one section for a gas well. Energy companies with rights to tracts of land that were smaller than the required size began to include in their leases the right to pool the leased lands with other lands in order to achieve the rights to an entire drilling spacing unit. However, a series of cases emphasized that this alone was not enough to validate the individual leases of each tract within the unit.

In Shell Oil Company v Gunderson, ${ }^{5}$ the lessee had leased a quarter section of land owned by Gunderson and pooled that land with a neighbouring quarter section, which it had also leased. The lessee drilled a successful gas well on the neighbouring lands and shut in production as it was entitled to under the terms of the lease. It then paid a shut-in royalty to the owner of the neighbouring land and to Gunderson and took the position that both leases remained in force throughout the period of deemed production.

When Gunderson challenged the continuing validity of the lease, the Supreme Court of Canada noted that the habendum clause of the lease stated that it continued for so long "as the leased substances or any of them are produced from the said lands." ${ }^{6}$ The Court interpreted the habendum literally and noted that under the terms of the lease, only the Gunderson lands were defined as "the said lands.” The Gunderson lease thus terminated because it could not be continued by deemed production that occurred on neighbouring lands rather than "the said lands."

\section{The Shut-In Well Provision}

From the early days of the industry, lease forms have given the lessee the right to shut in a completed well for a variety of reasons. As long as the requirements for a shut-in well are met and a shut-in royalty is paid annually in accordance with the terms of the lease, the shutin well is deemed to be a producing well for all the purposes of the lease. Although natural gas wells were frequently shut-in for long periods of time, it is only in the recent phase of Canadian case law that the shut-in well provision has proved to be fatal to a number of leases. Those cases have frequently found that the lessee failed to meet the prerequisites for exercising the right to shut in a well.

Freyberg $v$ Fletcher Challenge Oil and $\mathrm{Gas}^{7}$ raises important remedial questions that are discussed in Part III of this article. There, the lease failed because of the lessee's failure to meet the requirements of the shut-in well provision. The lease allowed a well to be shut-in where there was no production "as a result of the lack of an economical or profitable market.” ${ }^{\text {A }}$ well on Freyberg's land was shut-in from 1978 until 1998. In 1998 operations

[1960] SCR 424 [Gunderson]. See also Canadian Superior Oil of California, Ltd v Kanstrup (1964), [1965] SCR 92.

Gunderson, ibid at 428 [emphasis added].

2005 ABCA 46, 363 AR 35, rev’g 2002 ABQB 692, 323 AR 45 [Freyberg].

Ibid at para 28 . 
on Freyberg's land were commenced and a well was brought to production in 1999. Although shut-in well payments had been made throughout the twenty-year period, the Alberta Court of Appeal found that the lessee had failed to demonstrate there was a lack of an economical or profitable market during the whole of that time. As the lessee had not established that there was no market for the gas until 1999, the shut-in royalty payments had not served to extend the life of the lease. In Durish $v$ White Resource Management $L t d,{ }^{9}$ the lease allowed a well to be shut-in, in accordance with "good oil field practice." ${ }^{\prime 10}$ The lessee had arranged for Gulf Resources Company (Gulf) to drill a well under a farm-out agreement, but a dispute arose over the fees for the transmission and processing of gas charged by Gulf, and the well was shut-in. The Alberta Court of Appeal found that the decision to shut in the well because of a fee dispute had nothing to do with good oil field practice and, as a result, the lease had terminated.

\section{E. Production DURING THE EXTENDED TERM OF THE LEASE}

The freehold lease grants land to the lessee for the specified primary term and thereafter for an extended term, which can be defined in a variety of ways. In Montreal Trust Co v Williston Wildcatters, ${ }^{11}$ which will be discussed in detail in Part III of this article, the extended term allowed the lease to continue for so long as there was production or for so long as the lessee was engaged in or prosecuting "drilling or working operations"12 on the leased lands. The lease in that case was originally created in 1952. A successful oil well was drilled in 1955 and continued in production until 1990. There was no production for a sevenmonth period in 1990, and during that period, the lessee conducted only two acts that could be classified as "working operations" under the extension clause. In the first round of litigation that dealt with the validity of the lease, the trial judge described these actions of the lessee as "isolated acts, widely spaced in time and pursued only briefly. They can best be described as minimal and futile." ${ }^{3}$ The lease thus expired because after the lease had been extended by production, there was a period in which neither production nor operations were occurring.

\section{F. FAILURE TO RESPOND TO A NOTICE OF DEFAULT}

Most modern leases guard against the possibility that a breach might automatically terminate a lease through the device of a default clause. The clause requires the lessor to provide a notice of breach and then stipulates a period of grace to enable the lessee to remedy the breach. The lease terminates only if the lessee fails to remedy the breach within the stipulated period. This eventuality arose in Canpar Holdings Ltd v Petrobank Energy and Resources $L t d,{ }^{14}$ which will be discussed further in Part III of this article. The royalty clause in a petroleum and natural gas lease required the lessee to pay a royalty of 17.5 percent "of

(1987), 82 AR 66 (QB), aff'd (1988), 63 Alta LR (2d) 265 (CA) [Durish]. For a further example of the failure of a lease as a result of the improper application of the shut-in well provision see 549767 Alberta Ltd v Teg Holdings Ltd (1997), 70 ACWS (3d) 355 (Alta QB).

Durish, ibid at para 3.

2001 SKQB 360, 108 ACWS (3d) 383 at para 50, aff'd 2002 SKCA 91, 223 Sask R 276, leave to appeal to SCC refused, 29401 (30 September 2002) [Williston Wildcatters].

Ibid at para 4.

Ibid at para 50 .

(9 October 2009), Calgary 0601-05052 (Alta QB) [Canpar Holdings trial]. 
the greater of the actual price received ... or the current market value at the time and place of sale of all these substances produced from the lands, all without any deductions." ${ }^{\text {"15 }}$ The ultimate lessee wrongly calculated royalty payments based on its corporate average or pooling price, and failed to pay any royalties on gas that it used as fuel for its compressors, both on and off the leased lands. The lessors gave notice of default under the terms of the lease, but the lessee ignored the notice, apparently confident of its interpretation of the royalty clause. The Court found that the lessee's confidence was misplaced and that the lease terminated at the end of the period of grace. The Alberta Court of Appeal did not indicate any disagreement with this conclusion, but probably for the first time in Alberta, it granted relief against the forfeiture of an oil and gas lease.$^{16}$ In Canpar Holdings, it reinstated the lease and required the lessor to pay royalties in accordance with its terms. ${ }^{17}$

\section{The First Phase of Lease FaIlure Cases}

An examination of the consequences of failed leases in the first phase of the development of Canadian law reveals one cardinal feature. These cases typically resulted in an order requiring the lessee to vacate the lands, with the comment that if this result appeared harsh, it was a consequence of strict compliance with the terms of the lease chosen by the lessee. With a single exception, none of the cases decided during this decade provided the lessee with any compensation for benefits that may have been conferred on the owner of the leased lands. Indeed, the cases contain no suggestion that the lessee could recover even payments of money, in the form of delay rentals or shut-in royalties, which had been made to the owner in the mistaken belief that the lease remained valid.

The courts' failure to consider the consequences of an unexpectedly terminated lease probably arose from two causes. First, Canadian courts began to develop common threads in the previously disparate categories of restitution only in the mid-1970s. ${ }^{18}$ Until that time, there had been little systematic analysis of the fate of benefits transferred under failed transactions. Secondly, the case reports suggest that counsel, in the first phase cases, framed their arguments in an attempt to avoid the termination of leases, particularly through the doctrine of estoppel, rather than attempting to mitigate the consequences of termination. The estoppel arguments were almost universally unsuccessful ${ }^{19}$ but appeared to deflect the courts from examining whether the lessee could recover the value of any benefits that had been transferred under the failed lease.

\section{$15 \quad$ Ibid at 4.}

16 See Nigel Bankes, “Court of Appeal grants relief from forfeiture in an oil and gas lease case” (24 February 2011), online: ABlawg.ca <http://ablawg.ca/2011/02/24/court-of-appeal-grants-relief-fromforfeiture-in-an-oil-and-gas-lease-case/>. As Bankes points out, relief from forfeiture was available because this involved termination for cause, while most Canadian cases have involved leases that expressly terminated automatically, according to their own terms.

$17 \quad 2011$ ABCA 62, 331 DLR (4th) 588 [Canpar Holdings].

18 See e.g. Storthoaks (Rural Municipality of) v Mobil Oil Canada, Ltd (1975), [1976] 2 SCR 147. See also Peter D Maddaugh \& John D McCamus, The Law of Restitution, 2nd ed (Aurora, Ont: Canada Law Book, 2004) at 17-26.

19 The argument succeeded in the unique circumstances at Voyager Petroleums Ltd $v$ Vanguard Petroleums Ltd (1982), 47 AR 14 (QB), aff'd (1983), 47 AR 1 (CA), leave to appeal to SCC refused, (1983), 50 AR 82n. For the general failure of estoppel arguments, see Ballem, supra note 1 at 402-23; Nigel Bankes, "Termination of an Oil and Gas Lease, Covenants as to Title, and Assessment of Damages for Wrongful Severance of Natural Resources: A Comment on Williston Wildcattters” (2005) 68:1 Sask L Rev 23 at 31-33 [Bankes, "Termination”]. 
In order to examine the approach of the courts in the first phase of Canadian case law, it is necessary initially to distinguish cases in which there was no production of oil or gas from the failed lease from those which dealt with the proceeds of production that had been realized after the lease had terminated.

\section{A. FAILEd LeAses WHERE No Production OCCURRED}

Some cases in this category did not create any controversy. There was no realistic possibility of the lessee obtaining any form of compensation where the lease expired without the lessee having conducted any significant activity on the lands. The classic example of these cases occurred where the lessee mistakenly thought that a well drilled on lands with which the originally leased lands had been pooled was sufficient to validate the original lease. ${ }^{20}$ In these cases, no lasting improvements were left on the lands subject to the original lease, and the lessee could not point to any justification for compensation for activities that they may have conducted on those lands.

In contrast, significant problems arose where the lessee did create an improvement on the leased lands prior to termination. Typically, the improvement occurred where the lessee drilled a productive well on the leased lands only to discover that the lease had expired before the well could be brought into production. The most common cause of this situation occurred when the lessee decided that it was necessary to shut in a gas well but delayed the payment of the shut-in royalty until after the primary term had expired. These cases are a subgroup of those described in Part I.B of this article because the fatal gap between the capping of the well and the payment of the royalty meant that there was no actual or deemed production at the end of the primary term, resulting in the automatic termination of the lease. ${ }^{21}$

A variation of this problem occurred in Republic Resources Ltd v Ballem, ${ }^{22}$ where the lessee commenced a gas well during the term of the lease and completed it one week after the end of the primary term. It paid a shut-in royalty almost immediately after the completion of the well, but the lease terminated because there was no form of production in place when the primary term ended. In another of the shut-in royalty cases, the Alberta Court of Appeal recognized that this created a draconian result. It commented that "[i]t may appear harsh that the [lessee's] expenditure in drilling the well, as well as the benefit of the lease itself should be lost through a short delay in the payment of shut-in royalties," ${ }^{23}$ but the Court felt that this result was dictated by the terms of the lease. Although the lessee in Republic Resources argued that the lessor was incontrovertibly benefitted by the presence of a completed well on her lands, the Court felt unable to award the lessee any compensation for the cost of drilling the well. One of the present authors has argued that these results are contrary to the modern law of unjust enrichment because they provide the lessor with an uncompensated benefit, in the form of the well. The enrichment of the lessor is not immediate but will be

See especially Gunderson, supra note 5.

See e.g. Canadian Superior Oil Ltd v Paddon-Hughes Development Co Ltd, [1970] SCR 932.

(1981), 33 AR 385 (QB) [Republic Resources]. See also the discussion of Kininmonth, supra note 4, in Part II.B.2 of this article.

$23 \quad$ Canadian Superior Oil Ltd v Paddon-Hughes Development Co Ltd (1969), 3 DLR (3d) 10 at 19 (Alta $\mathrm{SC}(\mathrm{AD}))$. 
fully realized if and when the well is brought into production. ${ }^{24}$ However, none of the recent cases raise this issue and it will not be pursued further in this article.

\section{B. Failed Leases That Achieve Production}

Although there is a strong argument that the lessee should obtain a remedy in some cases where there has been no production under a failed lease, the argument is compelling where there has been actual production of petroleum or natural gas before the parties realize that the lease has failed. In these cases, the courts typically required the lessee to vacate the lands, with the result that the lessor received all the proceeds of future production. In addition, the lessor usually claimed all the proceeds of production from the date that the lease terminated, on the theory that after that time, the lessee had no right to the produced substances. However, the lessor was in the position of seeking all the benefits of the well and leaving the lessee to potentially bear all the costs only because of the lessee was mistaken as to its legal rights. These cases appeared in the first phase of the development of Canadian law and the courts approached the remedial problems that they raised as matters of first impression. However, before examining the Canadian authorities, it is important to note that at that stage the freehold lease in Canada still strongly resembled its American forbears. It is instructive to examine the approach taken by American courts to resolving the identical problems that arose under a very similar legal instrument, particularly because traces of the American approach are still found in recent Canadian cases.

\section{AMERICAN CASES ON FAILED LEASES}

The similarity between original Canadian freehold petroleum leases and their American counterparts meant that the American leases often failed for the same reasons. At the time of the first phase of Canadian cases, the American courts had already developed a great deal of experience in resolving the problems that were only beginning to emerge in Canada.

The American approach is simple in principle and is applied with considerable consistency. It is exemplified in the well-known case of Champlin Refining Co $v$ Aladdin Petroleum Corp ${ }^{25}$ in which Champlin Refining Co (Champlin) had purchased two leases from the state of Oklahoma, apparently without any warranty of title. It drilled two wells on the leased lands at a cost of more than $\$ 157,000$ and produced oil and gas from those wells for a considerable period of time. Champlin then discovered that it had no right to the lands in question and surrendered the lease and the producing wells to the rightful owners. Champlin also paid the rightful owners an amount of more than $\$ 310,000$, which represented the market value of all production taken from the wells, less the expenses of drilling, developing, and operating the wells (which totaled approximately \$197,000). Still dissatisfied, the rightful owners brought action for the total value of all the oil and gas that Champlin had produced from the lands. The Supreme Court of Oklahoma found that Champlin was mistaken in its view of the true ownership of the land and that it had unquestionably acted in good faith, in the belief that its leases were valid, when it drilled the 
wells and brought them into production. The Court awarded damages for the petroleum and natural gas that Champlin had produced on the basis of the value of the oil at the time of production, less the reasonable costs of production. Champlin's belief that it held all the required rights to the leased lands meant that it was a good faith trespasser, and it was only required to pay the net proceeds of production to the rightful owners. In contrast, if the Court had found that Champlin was a bad faith trespasser, it would have been required to disgorge all the proceeds of production from the lands in question.

Two features of the American case law are notable in the light of developments in Canada. First, as the Champlin case illustrates, the good faith trespasser will recover the reasonable costs of producing petroleum substances from the leased lands, or their actual costs if they are lower than the reasonable costs. If an efficient trespasser succeeded in bringing a well into production at a cost that was lower than the prevailing market rates, it would recover only its actual expenses. On the other hand, any unnecessary costs incurred by the trespasser will not be recovered. This distinction emphasizes that the purpose of allowing a mistaken producer to recover its costs is clearly to prevent what would otherwise have amounted to an unjust enrichment of the lawful owner at the expense of the trespasser. ${ }^{26}$

Second, although most American cases have concluded that the trespasser acted in good faith, ${ }^{27}$ the threshold for finding that a trespass was committed in bad faith is not as high as the Canadian cases suggest. One of the most widely quoted definitions states:

[T] he defendant must have an honest belief in the superiority of his right or title, and such belief must be a reasonable one in the light of the circumstances. The test is subjective in that he must have actual notice of the outstanding paramount right, and constructive notice is not sufficient. The test is objective in that he must not have acted with culpable negligence or with wilful disregard for the rights of others, and in that his belief in the superiority of his claim must be reasonable. ${ }^{28}$

The application of this principle is less strict than the definition implies. Most states placed the onus of proving good faith on the trespasser. A number of jurisdictions have found that the company acts in bad faith if it chooses to drill a well with the knowledge that there is an actual or pending claim over the validity of its rights. This approach has been extended to cases in which a company proceeded to production after a decision that the competing claim was invalid, but before a final appeal was heard. ${ }^{29}$ There is little doubt that the facts in some of the recent Canadian cases suggest that an argument of bad faith trespass might have been open to the lessor. ${ }^{30}$

John S Lowe, Oil and Gas Law in a Nutshell, 5th ed (St Paul, MN: Thomson Reuters, 2009) at 58. Ibid.

Eugene Kuntz, A Treatise on the Law of Oil and Gas (Cincinnati: Anderson, 1987) vol 1 at 315-16 [footnotes omitted].

Shell Oil Co v Manley Oil Corp, 50 F Supp 21 (Ill Dist Ct 1942).

See particularly Xerex Exploration Ltd v Petro-Canada, 2005 ABCA 224, 367 AR 201 [Xerex], discussed in Part III.C of this article and the argument in Bankes, "Termination," supra note 19 at 6163. 


\section{The Approach of CANAdian Courts IN PHASE ONE}

In the first phase of Canadian case law, three cases confronted the problem of accounting for the proceeds of production after the failure of a lease. None of the cases offer any analysis of the problem and the list of authorities cited suggests that the relevant arguments were not before the courts. The results of the cases can be placed on a spectrum. At one end, the court ignored the production that had occurred, and at the other, the court reached the conclusion that would have been appropriate only if the trespass had occurred in bad faith. In the middle of the spectrum, the only Supreme Court of Canada decision reached a result that is broadly consistent with the American cases of good faith trespass.

All three cases in the first phase involved the problem identified in the Kininmonth decision, where the lessee commenced a well within the primary term but failed to achieve production prior to its expiry. ${ }^{31}$ The cases uniformly found that this type of lease expired at the end of the primary term unless a well was actually in production at that time. ${ }^{32}$ It is a rarely discussed feature of the Kininmonth case that it also raised the question of the fate of the proceeds of production under the invalid lease. In that case, the lessee had produced oil from the well for a period of approximately 11 days after the lease expired. ${ }^{33}$ The lessor sought only a declaration that the lease had terminated and was successful on this point. He made no claim to the proceeds of production. Probably for this reason, and because of the short duration of the production, the Court did not deal with the proceeds of production in its reasons for judgment. It may be presumed that they remained in the hands of the lessee.

Paramount Petroleum and Mineral Corporation Ltd v Imperial Oil Ltd dealt with a problem that was identical to that which arose in Kininmonth, with the exception that the lessee continued the production of large volumes of oil for many years after the lease expired..$^{34}$ The Court found that the lessee was unaware of the nature of its rights until long after it brought the well into production. There is thus no doubt that the lessee was, in American terminology, a good faith trespasser, but nevertheless, the Court ordered an accounting "with respect to all oil, gas and other mineral substances taken from the said lands," 35 just as if the lessee had been a bad faith trespasser.

Long after the first phase of the development of Canadian law, the Manitoba Court of Appeal reached the same result as the Paramount decision in 1993. In Hill Estate $v$ Chevron Standard Ltd, ${ }^{36}$ Chevron Standard Ltd (Chevron) entered into a mineral lease with the wife of the mineral owner, who was acting under a power of attorney granted by her husband in 1978. Some four years later, both the mineral owner and his wife had died and Chevron

$31 \quad$ Supra note 4.

This type of clause also explains the decision in Republic Resources, supra note 22 (see Part II.A of this article).

Kininmonth, supra note 4 at 440 .

34 (1970), 73 WWR 417 (Sask QB) at 425 [Paramount]: The lessee held two leases covering one and a half sections of land. The Court found that only the lease covering a half section of land was invalid. By the time of the trial, the decision indicates that the well on the land included in the terminated lease had been in production for nearly 11 years and that the lessee had paid almost $\$ 77,000$ in royalties in respect of the entire one and a half sections.

35 Ibid at 434. John Ballem reported anecdotally that in the accounting that followed the decision in Paramount, the parties allowed the lessee to deduct the cost of drilling and completing the well. Supra note 1 at 386.

36 (1992), [1993] 2 WWR 545 (Man CA). 
notified the owner's estate that was about to commence drilling under its lease. The lawyer for the estate told Chevron that the power of attorney was invalid, because of the mental incapacity of the owner at the time it was granted, and that the lease was therefore void. Nevertheless, Chevron proceeded to drill a successful well and begin production.

The case was unusual. The Court decided that the lease was invalid, but then invited further argument on the consequences of that decision. ${ }^{37}$ The Court recognized that Chevron's actions in drilling the well had enriched the estate. However, it found that the estate was entitled to all the revenue generated by the sale of oil from the mineral estate, without any deduction for the costs of drilling or marketing the product. Under the traditional approach, this result could have been justified by classifying Chevron as a bad faith trespasser because of its decision to drill a well when it knew the lease might be void. However, the Court declined to pursue this reasoning and commented that equity would not "afford protection to a trespasser." ${ }^{38}$ In drilling a well without valid legal authority, Chevron had provided a juristic reason for the enrichment.

It is difficult to justify the decision to award the estate all the proceeds of production on this basis. The result is contrary to a 1971 decision of the Supreme Court of Canada, described in the following paragraph, and proved to be completely inconsistent with the direction adopted by the courts in the following decade, as described in Part III of this article.

Only the last of the first phase of Canadian cases gave an explicit indication that the lessee could retain some of the proceeds of production that had occurred after the lease was terminated. In Sohio Petroleum Co v Weyburn Security Co Ltd, ${ }^{39}$ Sohio Petroleum Co (Sohio) began production of oil some six weeks after the end of the lease and production continued for almost seven years before the lease was challenged. The lessor was successful in its action to require the lessee to vacate the land, but also sought an accounting for the value of all the oil produced from the leased lands. The accounting issue was dealt with only in the final substantive paragraph of the decision in the Saskatchewan Court of Appeal. It stated:

The respondent also sought an accounting of all petroleum, natural gas and related hydrocarbons removed from the land by the appellants, or damages in lieu thereof. The court has jurisdiction to grant this relief on terms which will be just and equitable to all parties involved. The appellant Sohio proceeded under a mistake as to its rights, and did not knowingly take an unfair advantage of the respondent's lack of appreciation of its legal rights. The appellants were first aware that their position was challenged when the writ of summons was served upon them. At that time the revenue which they had received from the sale of the production exceeded the amount they had expended. Under the circumstances, it would appear just and equitable to order the appellants to account for all benefits from production received by them after the date of service of the writ of summons upon them. ${ }^{40}$

$37 \quad$ Ibid at 569 .

$38 \quad$ Ibid at 561. The reference to equity is probably explained because Chevron argued the case for recovering its costs on the basis of a constructive trust. However, there appeared to be no need for a proprietary, rather than a personal remedy, in restitution.

39 [1971] SCR 81, aff'g (1969), 7 DLR (3d) 277 (Sask CA) [Sohio]. Ibid at 89. 
The case offers no explanation for this conclusion, other than the principle of justice and equity. As will be seen in the following section, recent case law has correctly identified this brief passage as central to Canadian law dealing with the proceeds of production. As a result, it has been subject to close scrutiny, but it has also been used to justify some surprising conclusions. It is therefore initially important to assess the probable meaning of the passage in the context of the Sohio decision. The statement is noteworthy in three respects. First, there is no indication that there was any significant argument on the question of whether the lessor should receive the proceeds of production. The reasons for judgment at all three levels cite no relevant authority on this question, and they are concerned almost entirely with the termination of the lease and the defence of estoppel. Second, the paragraph clearly establishes that the lessee was an innocent trespasser. Third, when faced with the lessor's claim to all the proceeds of production, the Court expresses a concern that Sohio should, at a minimum, recover its costs of production. Although the exhibits filed at trial in the Sohio case apparently contain details of Sohio's production, ${ }^{41}$ there is no indication that there was any detailed evidence on this point. The Saskatchewan Court of Appeal appeared to allow Sohio to retain the revenue as of the commencement of the action as a rough and ready formula to ensure that it had covered its costs.

It must be conceded that the meaning of the vital paragraph in the Sohio case is far from self-evident. The Saskatchewan Court of Appeal recently asserted that this shows that the Court adopted a just and equitable approach to the assessment of damages. ${ }^{42}$ However, the simplest explanation of both the reasoning and the result may well be that the Court instinctively applied the good faith trespasser rule. It is quite possible that the reference to the "just and equitable" nature of the order merely reflects the recognition that it would be wrong to allow the lessor to recover all the proceeds of production without bearing any of the costs. There is some support for this interpretation in the Supreme Court of Canada decision. Although the Court was content to reiterate the final paragraph of the judgment of the Saskatchewan Court of Appeal, set out above, unlike the Court of Appeal, it first noted that the lessor's claim for an accounting of all production after the lease had terminated was "subject to an allowance for expenses incurred by the appellants." 43 The decision seems to adopt a formula which ensured that Sohio recovered its expenses of production. Admittedly, on this view, Sohio should not have been allowed to retain any amount in excess of its actual expenditures if the evidence permitted this calculation to be made. However, as a matter of principle, the Supreme Court decision suggests that the amount retained by the lessee should not be determined by broad principles of justice and equity, but by an examination of the extent to which the lessor would otherwise be enriched by the innocent, but mistaken, actions of the lessee. The case can thus readily be seen as an application of the principle applied in Champlin, but without an exact assessment of the expenditures incurred by the lessee. [Williston Wildcatters (Remedies)].

Ibid at para 96.

Sohio, supra note 39 at 89 . Contrary to the assertion in Williston Wildcatters (Remedies), ibid, the reference to the lessor's claim for the net proceeds of production did not appear in the Court of Appeal decision. 


\section{LeASE FAILURE IN THE NEW MILlENNIUM}

\section{A. THE COMPENSATORY APPROACH}

The cases involving the unexpected termination of leases decided within the last decade take a radically different view of the position of the lessee. While the earlier cases, with the single exception of the Sohio decision, did not allow the lessee to obtain any compensation when a lease failed, the new wave of authority takes a markedly different approach. In each of the modern cases, the lessee was entitled to retain revenue from the failed lease at a level that could have considerably exceeded its costs of production.

The point of departure of the recent cases arises in part from framing the claim to damages upon the failure of a lease in the law of torts, because the lessee commits trespass by remaining on the lands after the termination of the lease. Nigel Bankes has cast doubt on this analysis by pointing out that under a conventional lease, a tenant who continues in possession at the end of the term of the lease without the landlord's dissent or assent does not commit trespass. He suggests that the proper cause of action in cases involving the oil and gas lease may lie in conversion. ${ }^{44}$ However, the Alberta Court of Appeal has correctly pointed out that there is a question of whether the holder of an interest in minerals has a sufficiently immediate right to the possession of substances not yet severed from the ground to support a conversion action. ${ }^{45}$ It is surely certain that an energy company which extracts resources from land owned by another person without a valid lease is violating a property right of that person. It is not necessary to resolve this debate for the purpose of contrasting the tortious approach to calculating damages, where the objective is placing the lessor in the position it would have occupied if the tort had not been committed, with the restitutionary approach of focusing on the extent to which the lessee has been enriched as a result of the wrong. However, it must be noted that the majority of Canadian cases treat the continued occupation of land after the termination of a mineral lease as trespass, and it is not obvious why the approach that courts have taken in the case of conventional leases should be extended to the profit à prendre created by a mineral lease.

The compensatory approach was initially developed by the Saskatchewan Court of Appeal and subsequently embraced by the Alberta Court of Queen's Bench in two of the leading cases of the past decade. In each case, the litigation was protracted and involved numerous judicial decisions. In Williston Wildcatters ${ }^{46}$ which was described in Part I.E of this article, the lease failed in 1990 because, after 35 years of production, there was an extended period during which neither production nor operations occurred on the leased lands. The lessee continued to conduct activities on the leased lands without realizing that the lease had terminated, and ultimately brought the well back into production. In 1993 the lessor commenced an action in which it successfully challenged the validity of the lease and sought

$44 \quad$ Bankes, “Termination,” supra note 19 at 52-55. Even though overholding tenants in a conventional lease may not commit trespass, they remain liable to a claim for the use and occupation of premises that is based on restitutionary principles as set out in Part IV.C of this article. See also Roberty Megarry \& William Wade, The Law of Real Property, 7th ed (London: Sweet \& Maxwell, 2008) at 773.

45 Xerex, supra note 30 at 243-44. Supra note 11 at paras 14-22. 
to recover the market value of all the oil taken from the leased lands after the lease had terminated.

The dispute in Freyberg also involved separate hearings on the validity of the lease and the remedies available to the lessor. Although the Alberta Court of Appeal found that the lessee's decision in 1978 to shut in the well was initially valid, it concluded that at some point before 1999 an economic market for gas existed and the lease had lapsed at that time. ${ }^{47}$ However, in 1999 neither party was aware that the lease had terminated. The lessee brought the well into production in December 1999, and production continued until February 2006. ${ }^{48}$ In the hearing that dealt with the remedies in this case, the lessor sought to recover the gain that the lessee had received during the entire period of production, in an amount exceeding $\$ 4.8$ million. $^{49}$

Both cases recognized that there were two possible approaches to compensating the lessor. The Courts described the restitutionary approach as resting on the theory that "a wrongdoer should not profit from his wrong” by removing "any benefit or gain from the hands of the defendant wrongdoer." 50 They treated the measurement of the actual recovery from the wrongdoer in restitution through a variation of the formula that examines the state of mind of the trespasser. In the case of bad faith trespass, the lessor will receive the value of the oil or gas, with a deduction only for the costs of transporting the substances to market. In the case of innocent trespass, the wrongdoer is entitled to deduct the costs of "severance, production and marketing."

Both cases refused to apply either version of the so-called restitutionary approach. Instead, they adopted a tortious measure of compensation with the objective of placing the lessor in the position it would have occupied if the wrong had not occurred. ${ }^{52}$ On the facts of each case, the Courts felt that the innocent trespass rule would have overcompensated the lessor through an award that exceeded the amount which could ever have been received from the exploitation of the minerals.

The possibility of overcompensation arose from the nature of each lessor. In Williston Wildcatters, Montreal Trust Company (Montreal Trust) held the lease as a bare trustee. Under the terms of the trust agreement, it had no right to produce oil and gas from the leased lands, and if it had known that the lease had lapsed, it would have had no choice but to engage a third party to carry on production. The plaintiff in Freyberg had no similar restrictions on her legal capacity, but she had not had any significant involvement in business throughout her life and the Court found that she could not have operated the well by herself. Once the original lease was terminated she, like Montreal Trust, would have been required to enter a new lease arrangement with a different operator. In the Courts' view, neither plaintiff would ever have been in the position to earn the net proceeds of production and

Supra note 7 at para 137. Leave to appeal to the Supreme Court of Canada on the termination issue was refused (2005), 363 AR 35.

Freyberg v Fletcher Challenge Oil and Gas Inc, 2007 ABQB 353, 428 AR 102 at para 11 [Freyberg (Remedies)].

Ibid at para 92.

Ibid at para 98.

Ibid at para 99.

Ibid at para 100; Williston Wildcatters (Remedies), supra note 41 at paras 110-11. 
would thus have received a windfall from an award based in restitution. In contrast, an award based on tort principles fully compensated the plaintiffs by examining the bonus and royalty arrangements that they would have been able to negotiate at the time the lease terminated. In Freyberg, the Court found in principle that the plaintiff would have received a bonus payment and royalty rate significantly higher than the industry norm because the existence of a proven well meant that the lessee would not have to bear the normal risk of drilling a well that might have been unsuccessful. ${ }^{53}$ In Williston Wildcatters, the Court had sufficient evidence to quantify the damages. It concluded that, when the original lease terminated, the lessor would have been able to obtain a bonus of $\$ 6,400$ for signing a new lease and a royalty rate of 18 percent, rather than the 12.5 percent stipulated in the original lease. ${ }^{54}$

Both decisions raised novel points in oil and gas law in Canada. They can best be understood by examining their historical sources and their impact on future decisions.

\section{B. HistoricAl ANTECEDENTS}

Although none of the earlier cases in Canadian oil and gas law had explicitly taken a compensatory approach to calculating the loss suffered by the lessor, it is important to note that Williston Wildcatters and Freyberg did not come as bolts from the blue. Both cases relied on an established common law line of authority in mining law, and in particular, on the well-known decision in Livingstone $v$ Rawyards Coal Co ${ }^{55}$ Livingstone had purchased approximately 1.5 acres of land, on which 30 miners' cottages were located, in the middle of a coalfield leased to the respondents. Both Livingstone and the vendors thought that he had purchased only the surface of the land and that the vendors had reserved the property in all the coal beneath the surface. Acting on this belief, the respondents, in the course of extracting coal from the surrounding lands, also removed 5,895 tons of coal from beneath Livingstone's 1.5 acre parcel. They acted in "perfect ignorance” and with "no bad faith, nor sinister intention" 56 in removing the coal from Livingstone's land. When the mining operations were completed and all the coal had been sold, Livingstone discovered that the original conveyance had inadvertently transferred to him the property in the coal beneath his land.

Livingstone sought the value of all the coal removed from his land, with an allowance for the costs incurred by the respondents in bringing the coal to the surface. This formula would have yielded approximately $£ 515$. However, there were two obstacles to this claim. First, Livingstone could not have mined the coal profitably on his own because of the very small parcel of land which he owned. The only practical method by which he could have obtained value for the coal was by arranging for the respondents to remove his coal in the course of their own operations. Second, his own witnesses stated that they would have advised him to sell his coal subject to a royalty that would yield approximately $£ 171$ and to recover the cost

Freyberg (Remedies), ibid at para 141. The Court required further evidence to establish the plaintiff's actual loss, but the case was subsequently settled. See Chris Simard, David Holub \& Larina Taylor, "Lady Freyberg: Examples of How Contemporary Courts in Alberta Approach the Modern Business Realities of the Freehold Petroleum and Natural Gas Lease” (2009) 46:2 Alta L Rev 299. Williston Wildcatters, supra note 11 at para 49, aff'd Williston Wildcatters (Remedies), supra note 41 at paras $17,112-15$.

(1880) 5 AC 25 (HL (Scot)) [Livingstone].

Ibid at 26. 
of repairing damages to his houses caused by subsidence from the mining operations. On this basis, the House of Lords affirmed the award of $£ 200$ damages to Livingstone. ${ }^{57}$

Livingstone provides a direct link in the lineage of the recent cases in Western Canada. The insistence by the House of Lords on calculating Livingstone's loss on a compensatory measure where he could not economically or practically have developed the coal on his own explains the adoption of the same approach where the Courts found that the lessees did not have the legal capacity, in Williston Wildcatters, or the business acumen, in Freyberg, to exploit their own resources. The cases have thus undoubtedly established in Canada an alternative analysis of remedies in the case of a terminated lease. The following section will examine the impact of the alternative analysis in two subsequent decisions.

\section{THE EXTENSION OF THE COMPENSATORY APPROACH}

The adoption of a compensatory approach to damages by the Saskatchewan Court of Appeal was bound to have an effect on subsequent oil and gas litigation. The extent of the potential impact of the difference between the compensatory and the restitutionary approaches was illustrated almost immediately in a complex case of trespass that arose from Alberta's practice of allocating petroleum and natural gas rights in limited geological strata. In Xerex Exploration Ltd v Petro-Canada, ${ }^{58}$ the Crown had granted the shallow petroleum and natural gas rights to the base of the Bluesky-Bullhead formations to the appellant. Xerex Exploration Ltd (Xerex) held the deep rights beneath those formations. The appellant obtained a licence to drill the 1-1 Well in order to explore its rights and the regulator permitted it to continue to drill a further 15 metres below the base of the Bluesky-Bullhead formations. This extension, known as the "over-hole," was granted for the sole purpose of accommodating the appellant's logging tools and casing. ${ }^{59}$ When the appellant drilled the over-hole, it penetrated the deep zone, where Xerex held the mineral rights. Despite the limited purposes of the permission to drill the extension of the well, the appellant took the opportunity of taking drill cutting samples at one metre intervals in the over-hole. The samples showed promising signs of the presence of oil in the deep zone.

The appellant immediately began negotiations to acquire the rights to the deep zone from Xerex. During the negotiations, Xerex asked whether the appellant had drilled into the deep zone. The appellant fraudulently misrepresented that it had not done so and failed to disclose that it had drilled a further seven metres into the deep zone and taken more samples in the days following the beginning of negotiations. As a result of the negotiations, in November 1996, Xerex sold its rights to the deep zone in exchange for a gross overriding royalty of 3 percent on any production obtained by the appellant. ${ }^{60}$

About 18 months after acquiring Xerex's rights to the deep zone, the appellant sold a number of properties, including the 1-1 Well, to another company for the price of approximately $\$ 1.4$ million. ${ }^{61}$ In the spring of 1999 , Xerex learned by chance that the $1-1$

Ibid at 32-33.

Supra note 30.

Ibid at para 15 .

Ibid at paras 24-25.

Ibid at para 29. 
Well had proved to be very productive. The discovery was particularly surprising, as Xerex had not received any royalties from the production, and it commenced proceedings against both the appellant and the new owner of the 1-1 Well. By the time of the trial, the net revenue for the 1-1 Well exceeded \$3.5 million and its future net cash flow was estimated at almost $\$ 12.7$ million. ${ }^{62}$

Two facts in particular militated against Xerex recovering the proceeds of the production from its deep rights in this case. Although Xerex was an oil company, it was far from certain that it would have been able to exploit its deep rights in the absence of the appellant's intervention. When the appellant began negotiations to acquire the rights to the deep zone, Xerex's rights were due to expire unless it fulfilled the demanding requirement of drilling a potentially productive well within 20 days. Second, in hindsight, the appellant had made a bad decision in selling the very valuable 1-1 Well and other properties for \$1.4 million. The difference between the selling price of the entire group of properties and the value of the ultimate production of the 1-1 Well meant that a remedy based on the extent by which the appellant had been enriched by its wrongdoing was much less attractive than a compensatory remedy. As a result, Xerex sought damages to place the company in the position it would have occupied if it had been properly informed of the appellant's drilling activities in the deep zone. The Alberta Court of Appeal affirmed the decision of the trial judge that, in the absence of the appellant's misrepresentation and failure to disclose the extent of its drilling into the deep zone, Xerex would have negotiated a farm-out agreement entitling it to 50 percent of the net profits of the 1-1 Well, which were quantified at more than $\$ 8.1$ million. ${ }^{63}$

It is necessary to make only a slight change to the facts of this case in order to demonstrate the potentially dramatic difference between the compensatory and restitutionary approaches. If the appellant had retained ownership of the 1-1 Well and had contacted Xerex further in advance of the termination of its rights, so that Xerex might have been able to drill its own well in the deep zone, an interesting array of possibilities would have arisen. The appellant's conduct would almost certainly have been classified as a bad faith trespass, and thus Xerex would have recovered all of the proceeds of production (under the American approach) or the proceeds of production minus the costs of transporting the oil to market (as suggested in Williston Wildcatters). Even if the appellant's trespass had been classified as innocent, Xerex would presumably have been able to show that it could have produced oil from the deep rights on its own and recovered the net proceeds of production in the amount of $\$ 16.26$ million. ${ }^{64}$

A more traditional approach was adopted at the Canpar Holdings trial. As indicated in Part I.F of this article, the trial judge found that a gas lease had terminated through the lessee's wrongful calculation of royalties and failure to respond to a subsequent notice of default. The Court then addressed the problem of fashioning the appropriate remedy for the gas that the lessee had produced after the date of termination. It noted that the Court in

The trial judge in the Xerex decision found that the past and future net profit from the 1-1 Well was $\$ 16,266,000$, ibid. The Court of Appeal decision suggested an alternative avenue to this result by finding that the appellant was in a fiduciary relationship with Xerex, thus rendering the appellant liable to account to Xerex for its profit. See Maddaugh \& McCamus, supra note 18 at 828-29. 
Freyberg had adopted the compensatory principle for the award of damages and that, in the present case, the lessee's conduct was "far less egregious" 65 than that of the defendant in Freyberg. This comment might suggest an inclination to award a remedy which was at least as mild as that awarded in Freyberg, but the Court then granted the lessor a remedy based on the proceeds of production after the termination of the lease, minus transportation costs. There was no explanation for this result in the original oral judgment, although in clarifying the reasons, the trial judge noted that the lessors could have produced from the wells themselves, thus distinguishing the actual calculation of damages from Freyberg. ${ }^{66}$

The Alberta Court of Appeal's decision to relieve against the forfeiture of the gas lease avoided the necessity of discussing the applicable principles of damages, although the Court did note that the trial decision had created a windfall by requiring the lessee to pay both the net proceeds of production and the royalty at the rate prescribed in the lease. ${ }^{67}$

The facts of the Xerex case seem to illustrate the potentially large differences that can occur under the so-called restitutionary approach and the compensatory approach adopted in Williston Wildcatters and Freyberg. The award of damages at trial in Canpar Holdings suggests that there is a degree of confusion in the application of the new approach. The following section will attempt to disentangle the conflicting principles that are now found in Canadian case law.

\section{A PRinCiPled APPRoACH to OVERLAPPING REMEDIES}

\section{A. CRiticism of THE NeW ApProAch}

The new approach to the question of compensation upon the unexpected termination of a lease drew severe criticism from distinguished authors. Both John Ballem and Nigel Bankes delivered strong attacks on the decisions on the basis of four major objections, each of which will be considered in turn.

\section{INCONSISTENCY WITH OTHER AUTHORITIES IN NATURAL RESOURCES LAW}

Perhaps the primary critique of the new approach articulated in Williston Wildcatters and Freyberg is that it represents a significant departure from the way that the courts have determined a proper remedy in cases that involve the wrongful severance of natural resources. Bankes argues that the vast majority of such cases are restitutionary in nature and that the corresponding remedies are best understood as falling within one of three categories: (1) allowing the lessee no deductions for the costs associated with severance; (2) allowing the lessee to deduct post-severance costs only; and (3) allowing the lessee to deduct pre- and post-severance costs. ${ }^{68}$

Canpar Holdings trial, supra note 14 at 7.

Ibid at 8.

Canpar Holdings, supra note 17 at para 56.

Bankes, “Termination,” supra note 19 at 57, 63-77. 
In analyzing the compensatory approach that was taken in Williston Wildcatters and Freyberg, which Professor Bankes refers to as the "costs-plus approach,” he suggests that the House of Lords in Livingstone ${ }^{69}$ did not intend to develop a mild compensatory rule of broad application in the way that the recent cases suggest. ${ }^{70}$ Rather, the Court emphasized that the facts in Livingstone were peculiar (that is, well outside of the norm) and gave rise to a compensatory measure of damages on the particular facts of the case. Bankes quotes Lord Blackburn who stated in Livingstone:

My Lords, I wish only to say one word to guard against any misapprehension on a point which I at first a little misapprehended. I do not think that this decision of the Court of Session is that the royalty is the measure of damages. It is only that it is evidence of the value which is the measure of the damages. ${ }^{71}$

Bankes thus argues that the bulk of the authority on wrongful severance supports a restitutionary approach and that the compensatory approach that has been so prominent in recent Canadian cases was meant to be narrowly confined.

\section{FAILURE TO ENSURE THAT TORTFEASORS SHOULD NOT PROFIT FROM THEIR WRONGS}

Although the general approach to damages in tort is based upon the compensation principle and is designed to restore the plaintiff to the position it would have occupied if the wrong had not occurred, a competing principle in the context of wrongful severance of natural resources is that tortfeasors should not benefit from their wrongs. ${ }^{72}$ The decision in $A G v$ Blake $^{73}$ is particularly informative in this regard. Blake, though concerned with a breach of contract, provided an important caveat to the standard compensatory approach when Lord Nicholls stated:

Damages are measured by the plaintiff's loss, not the defendant's gain. But the common law, pragmatic as ever, has long recognised that there are many commonplace situations where a strict application this principle would not do justice between the parties. Then compensation for the wrong done to the plaintiff is measured by a different yardstick. A trespasser who enters another's land may cause the landowner no financial loss. In such a case damages are measured by the benefit received by the trespasser, namely, by his use of the land. The same principle is applied where the wrong consists of use of another's land for depositing waste, or by using a path across the land or using passages in an underground mine. In this type of case the damages recoverable will be, in short, the price a reasonable person would pay for the right of user.

In some instances the common law itself afforded a wronged party a choice of remedies. A notable example is the wrong of conversion. A person whose goods were wrongfully converted by another had a choice of

See Part III.B of this article.

Bankes, "Termination,” supra note 19 at 68-69.

Ibid at 69, citing Livingstone, supra note 55 at 42-43 [emphasis in Bankes, “Termination”].

Ibid at 75.

[2001] 1 AC 268 (HL (Eng)) [Blake]. 
two remedies against the wrongdoer. He could recover damages, in respect of the loss he had sustained by the conversion. Or he could recover the proceeds of the conversion obtained by the defendant. ${ }^{74}$

In effect it is argued that the compensatory approach fails to give sufficient weight to a significant body of authority that allows for a plaintiff to make a restitutionary or gains-based claim so as to prevent the tortfeasor from profiting from its wrong.

\section{FAILURE TO RESPECT THE PROPERTY RIGHTS OF THE LESSOR}

A third line of criticism argues that the compensatory approach diminishes the protection provided to the property rights of the lessor. In determining whether to apply the restitutionary or the compensatory approach, the courts must inquire into whether the lessor could or would have produced the mineral estate on its own. The late John Ballem noted that this "requires the court to delve into the affairs of the plaintiff, a task for which it is illequipped." 75

The argument continues that the distinction invariably results in some lessors being more "equal” than others. In cases involving continued production after a lease has failed, lessors who are sophisticated commercial oil and gas producers are more likely to receive significant damages than individual lessors who are unable to demonstrate that they could have produced their minerals on their own. ${ }^{76}$

\section{LACK OF INCENTIVE TO DisCONTINUE PRODUCTION UNDER A CHALLENGED LEASE}

As illustrated in Williston Wildcatters and Freyberg, the compensatory approach can result in the wrongdoer paying damages in the form of a bonus payment and an increased royalty rate. This creates the risk that an overholding lessee may look at the minor potential financial consequences of continuing to produce and decide, from a business perspective, that it is worth the risk. As Ballem pointed out:

\footnotetext{
If the bonus consideration and the royalty rate happened to be the same as were commonly obtained at the time the lease terminated, it would appear that the mineral owner would not be entitled to any compensation whatsoever. This despite the fact that the lessee had enjoyed revenue from the production of minerals to which it had no legal title. ${ }^{77}$
}

This could tempt the overholding lessee to continue in possession of the leased lands and obtain production revenues while participating in a protracted legal battle over the validity of the underlying lease, especially if, as recent case law suggests, this conduct would not be seen as acting in bad faith but merely an example of a lessee acting upon its view of its legal rights. ${ }^{78}$

Ibid at 278-80 [citations omitted].

John Bishop Ballem, “The Further Adventures and Strange Afterlife of the Oil and Gas Lease” (2006) 44:2 Alta L Rev 429 at 438.

Ibid.

Ibid.

Ibid. 
The likelihood that there will be more decisions on the impact of unexpectedly terminated leases requires an analysis of the extent to which these criticisms are justified and an examination of whether the gulf between the compensatory and restitutionary approaches is as great as the authors suggest. From the viewpoint of principle and certainty, the accounts of the evolution of the compensatory principle in Canada creates two major issues, which will be considered in turn.

\section{B. WHEN IS A RESTITUTIONARY REMEDY AVAILABLE?}

The first issue occurs as a result of the approach to the problems that arise when the plaintiff has a choice of overlapping remedies, each of which may create a different measure of damages. In Williston Wildcatters, the lessor disputed the trial judge's damage assessment based on compensation instead of restitution and claimed the full value of its minerals, less the costs of production and marketing, in order to prevent the original lessee from profiting from its wrongdoing. ${ }^{79}$ The Court appeared to reject the restitutionary approach and applied the compensatory principle which, in its view, "derives from equity and has as its goal doing justice and equity between all the parties on the facts." ${ }^{80}$ The Court in Freyberg saw a stark choice between the two approaches and firmly applied the compensatory principle of tort law in order to avoid conferring a windfall on the lessor. In essence both Courts rejected the lessor's claim in restitution because they felt that its result would be excessively generous and that it should be ignored on the grounds of justice and equity.

The denial of the restitutionary remedy on these grounds is both alarming and contrary to the normal approach when overlapping remedies are available in a particular case. In essence, it treats restitution as a guide to the quantification of damages, rather than an independent cause of action. In principle, plaintiffs who establish the elements of an action in unjust enrichment are entitled to a restitutionary remedy and the courts have no business in substituting a tort remedy on the grounds that it seems fairer. As Justice La Forest stated:

[A] claim for an unjust enrichment, is concerned with giving back to someone something that has been taken from them (a restitutionary proprietary award) or its equivalent value (a personal restitutionary award) ... [the function] "is to ensure that where a plaintiff has been deprived of wealth that is either in his possession or would have accrued for his benefit, it is restored to him. The measure of restitutionary recovery is the gain the [defendant] made at the [plaintiff's] expense.”81

The claims of the lessors in both Williston Wildcatters and Freyberg have a firm historical foundation in an area of restitution that was formerly (and misleadingly) known as "waiver of tort.” The underlying principle of the cases in this area was that the plaintiff gave up the right to sue in tort and instead elected "to base the claim in restitution, thereby seeking to recoup the benefits that the defendant has derived from the tortious conduct." 82 Indeed, conversion and trespass provide some of the most familiar examples of recovery under this

Williston Wildcatters (Remedies), supra note 41 at para 69.

Ibid at para 110 .

Citadel General Assurance Co v Lloyds Bank Canada, [1997] 3 SCR 805 at para 30 [Citadel General Assurance], citing Air Canada v British Columbia, [1989] 1 SCR 1161 at 1202-203.

Maddaugh \& McCamus, supra note 18 at 727. 
heading. ${ }^{83}$ They are now understood as examples of restitution for wrongdoing ${ }^{84}$ and reflect the general principle that a defendant may be required to restore the value of a benefit that was gained not just from a tort, but from any type of wrongdoing. The action is initially triggered by the occurrence of a wrong, although its purpose is to prevent the defendant from being unjustly enriched through wrongdoing.

In cases such as Williston Wildcatters and Freyberg, the plaintiffs fulfilled the requirements of actions in both tort and restitution. A broadly analogous problem arose in a series of Canadian cases in which the courts confronted cases where the defendant's conduct created both a breach of contract and a tort. At first, the courts had difficulty with the existence of overlapping remedies, each of which were subject to different rules and measures of damages. Famously, Justice Pigeon once proclaimed in the Supreme Court of Canada that "the basis of tort liability considered in Hedley Byrne is inapplicable to any case where the relationship between the parties is governed by a contract, unless the negligence relied on can properly be considered as an 'independent tort' unconnected with the performance of that contract." ${ }^{85}$ It took more than a decade for the courts to recognize that the same set of facts could create concurrent liability in contract and tort, unless a contractual provision excluded or limited the tort action. The general principle allowed the plaintiff "to assert the cause of action that appears to be most advantageous to him in respect of any particular legal consequence.”86

There can surely be no argument that prevents this principle from applying where the same set of facts fulfills the requirements of an action in tort and an action in restitution. The plaintiff must be able to assert the most advantageous cause of action available in the particular case and a court cannot rule out either action on the flimsy ground that its result may be unjust or inequitable. Any suggestion to that effect in Williston Wildcatters or Freyberg must be wrong. In the view of the authors, it is correct to say that the plaintiff may choose to pursue a remedy in restitution when the elements of that action are fulfilled, even where the underlying facts also create liability in tort. However, this conclusion does not end the matter. An examination of the modern law of restitution suggests that in both cases the Courts were justified in their concern over awarding the net proceeds of production to the plaintiff. It is quite possible that those courts achieved the right result, but for the wrong reasons.

\section{THE MEASURE OF RECOVERY IN RESTITUTION}

Although the critiques of Williston Wildcatters and Freyberg provide a great deal of valuable analysis, they go a step too far in arguing that the normal consequence of applying the restitutionary approach involves the recovery of some measure of the proceeds of production. The same can be said of a statement to the same effect made in an earlier article

James Edelman, Gain-Based Damages: Contract, Tort, Equity and Intellectual Property (Oxford: Hart Publishing, 2002) at 123, 137-40.

Kingstreet Investments Ltd v New Brunswick, 2007 SCC 1, [2007] 1 SCR 3 at para 33. The Supreme Court of Canada recognized that "[t]here are at least two distinct categories of restitution: (1) restitution for wrongdoing; and (2) restitution for unjust enrichment."

$J$ Nunes Diamonds Ltd v Dominion Electric Protection Co, [1972] SCR 769 at 777-78, citing Hedley Byrne \& Co Ltd v Heller \& Partners Ltd, [1964] AC 465.

Central Trust Co v Rafuse, [1986] 2 SCR 147 at 206. 
by one of the present authors. ${ }^{87}$ Recent Canadian decisions also assumed that an award in restitution would produce this result. It is true that the American cases on good faith trespass, as well as (in the writers' view) the Sohio decision, suggest that the innocent trespasser must pay to the lessor the net proceeds of production after the termination of the lease. However, the understanding of restitution has developed rapidly over the last quarter century and it is important to examine whether these assumptions remain valid. It is often the case that when principles from private law are adopted into oil and gas law, they are perpetuated in subsequent oil and gas cases with little reference to developments in their original context. ${ }^{88}$ As a result, while it is true cases such as Williston Wildcatters that adopt the compensatory royalty approach "are inconsistent with the bulk of authority” in natural resource severance cases, ${ }^{89}$ it is important to examine whether the bulk of authority continues to represent the modern law of restitution.

There are two methods of awarding damages based on the gain made by the defendant as a result of a wrong. Restitutionary damages are designed to reverse a wrongful transfer value from the plaintiff to the defendant. James Edelman provides an example that is similar in principle to some of the cases involving oil and gas leases. Following the expiry of a lease, the tenant wrongfully remained on the landlord's premises, thus committing trespass to land. The value wrongfully transferred to the tenant took the form of the use of the landlord's premises. The restitutionary damages for the wrong committed by the tenant were measured by the fair market value for the wrongful use of the premises gained by the tenant. ${ }^{90}$ The function of the award of restitutionary damages in this case was not to compensate for the loss suffered by the landlord, but to reverse the transfer of wealth from the landlord by subtracting the objective benefit received by the tenant as a result of the wrong it had committed. In quantifying damages, it did not matter whether the tenant had made a spectacular profit or incurred a loss as a result of the occupation of the landlord's premises. In the words of Lord Nicholls in Blake, the damages were based on "the price a reasonable person would pay for the right of user."91

In contrast to restitutionary damages, the defendant's gain can also be stripped by disgorgement damages, which require the surrender of the profits resulting from the wrong. In the entire field of civil remedies, disgorgement is an unusual remedy. Unless a case can be made for exemplary damages, it is rare for any award to strip profits from the defendant, particularly where a breach of duty is not wilful. It is equally rare in unjust enrichment. It is simply not the case as a general principle that a tortfeasor or other wrongdoer is never permitted to profit from a wrong. In the language of the American Restatement (Third) of Restitution \& Unjust Enrichment, disgorgement is found in some cases involving a "calculating" or a "conscious" wrongdoer, ${ }^{92}$ as in the case of a bad faith trespass or one who knowingly publishes a libellous book. ${ }^{93}$ In Blake, the Court awarded disgorgement in the case

See Percy, supra note 24 at 113.

Ibid at 105 .

Bankes, "Termination," supra note 19 at 57.

Edelman, supra note 83 at 67 . The present account of restitutionary damages draws heavily from chapter three of this book.

Supra note 73 at 278.

Restatement (Third) of Restitution \& Unjust Enrichment § 40 Commentary, §52.2 (Draft 2011)

[American Restatement].

See e.g. Cassell \& Co Ltd v Broome, [1972] AC 1027 (HL (Eng)). 
of deliberate, criminal breaches of contract and a failure to comply with an undertaking that was akin to a fiduciary obligation. ${ }^{94}$

In Canada, a well-known example of disgorgement occurred in Lac Minerals Ltd v International Corona Resources $L t d,{ }^{95}$ in which Lac Minerals Ltd (Lac Minerals) cynically, and in breach of confidence, used information obtained during negotiations with International Corona Resources Ltd to acquire and make large profits from land containing a rich gold deposit. In this case, the unique nature of the land persuaded the Court to make a proprietary award, by requiring Lac Minerals to disgorge the property itself, through the device of the remedial constructive trust. Disgorgement damages are also awarded to protect certain institutions by removing the prospect of gain from even innocent wrongdoing. This explains the use of disgorgement in cases of breach of fiduciary duty, where the courts are vitally concerned to hold fiduciaries to the duties they have assumed. As the Supreme Court of Canada recently noted, "disgorgement is imposed to serve a prophylactic purpose, the relevant causation is the breach of a fiduciary duty and the defendant's gain (not the plaintiff's loss). Denying [the wrongdoer] profit generated by the financial interest that constituted his conflict teaches faithless fiduciaries that conflicts of interest do not pay."

Where a court awards the lessor the net proceeds of production upon the termination of the lease, it is in essence requiring disgorgement, in the form of stripping the profits of tortious production from the lessee. Yet it is impossible to describe the lessee in most of the Canadian cases as a "conscious" or "calculating” or even as a deliberate wrongdoer. The lessee is subject to the normal measure of damages in the law of torts and the lessor may well have a restitutionary remedy, but neither of these approaches is likely to result in disgorgement. The underlying principle of damage awards throughout private law is designed to ensure that the plaintiffs are compensated for losses that they have suffered. Those who fail to respect property rights must pay the losses of the owner, unless their conduct is so egregious as to attract punitive damages.

It is true that a claim for restitution for wrongdoing changes the focus of inquiry from the loss suffered by the lessor to the enrichment obtained by the lessee as a result of its wrongdoing. The normal remedy in the case of restitution for wrongdoing, in the absence of conscious wrongdoing or the need to protect vital institutions such as fiduciary relationships, focuses on what the lessee gained from the wrongful occupation of the leased lands. In the words of the Supreme Court of Canada, the function of a restitutionary remedy is to give back to someone "something that has been taken from them .... or its equivalent value" ${ }^{\text {"97 }}$ or, more simply put, restitution refers to "the reversal of a transfer of value from a claimant to a defendant."98

The application of this principle to terminated leases must involve an examination of the value transferred from the lessor to the lessee when the lease came to an end. At that time, the plaintiff lessor "has clearly been deprived, as a result of the defendant's wrongdoing, of

Supra note 73 at $287-88$.

[1989] 2 SCR 574.

Strother v 3464920 Canada Inc, 2007 SCC 24, [2007] 2 SCR 177 at para 77.

See Citadel General Assurance, supra note 81 at para 30.

Edelman, supra note 83 at 36. 
the opportunity to rent the property to the defendant [or to another company] for the plaintiff's purposes at a fair return."99 In the cases considered in this article, because a commercial well now exists on land owned by the lessor, the benefit or value transferred to the lessee should be measured by the return that the lessor would have been able to command by entering into a new lease with either the defendant or another lessee. This approach suggests that the courts may have been on the right track in Williston Wildcatters and Freyberg when they enquired into the bonus and royalty rate that would have been payable at the time the lease was terminated. However, this result would not occur because the principles of justice and equity somehow deprived the lessor of seeking a restitutionary remedy. The appeal to those principles suggests that the assessment of damages is discretionary, rather than guided by well-established principles. In fact, the results in these cases are entirely consistent with an award of restitution.

The question then arises of the quantification of an award of damages when, as sometimes occurs in the petroleum industry, ${ }^{100}$ the lessor is capable of producing the land itself or perhaps arranging production through a contract operator. Both Williston Wildcatters and Freyberg recognized, at least by implication, that the lessor might have a successful claim for the net proceeds of production in this situation. However, perhaps contrary to suggestions in those cases, this result would occur as a result of compensatory damages in the law of torts rather than as an award of restitutionary damages for tortious wrongdoing. An award in restitution would still be measured by the return that the lessor would have been able to obtain at the time the original lease terminated. However, the lessor has a strong argument that an award of the net proceeds of production would be required to place it in the position it would have occupied if the tort had not occurred.

This conclusion suggests that there might be a divergence between Canadian and American oil and gas law on the effect of an unexpectedly terminated lease. However, the American case law is not entirely consistent. Although many decisions continue to award the net proceeds of production in the case of terminated leases, others suggest that the appropriate measure of damages for unofficious trespass is compensatory and should based on the award of an appropriate royalty to the lessor. In Beck v Northern Natural Gas Company, ${ }^{101}$ the gas company was commissioned by state and federal authorities to store gas in the Viola formation, where it held the storage rights. However, the gas company was able to store a much greater amount of gas than originally contemplated because the gas had migrated to a lower formation in which it did not hold the storage rights. The case posed a classic conflict, because the fair rental value of storage in the lower formation was \$2.3 million, but the gas company was able to generate additional profits of $\$ 12$ million as a result of inadvertently using the additional storage space without authorization. The claimants had originally been awarded damages based on the reasonable rental rate for the lower formation, but appealed on the basis that they were entitled to an award of the profits that arose from the gas company's trespass. Their case for additional damages was dismissed because a remedy based in an unjust enrichment did not justify profit stripping. The purpose of profit 
stripping was not to reverse a transferred enrichment, but to act as a deterrent in the case of bad faith trespass.

The American Restatement also reflects the approach of the Beck case and recent Canadian decisions. Section 40 of the American Restatement recognizes that the person who obtains a benefit by an act of trespass or conversion is liable in restitution to the victim of the wrong. ${ }^{102}$ The commentary on the relevant article of the American Restatement states that the conscious wrongdoer will be stripped of gains that result from unauthorized interference with another's property. However, the restitutionary liability of the defendant without fault will not exceed the value obtained in the transaction for which liability is imposed. As a result, innocent trespassers and converters are liable in restitution for the value of what they have gained, usually measured by the cost of a licence (representing the fair value of obtaining access to the lands), but not for consequential gains. These principles are expanded in Section 51, where the remedy of eliminating profit from wrongdoing through disgorgement is specifically restricted to the case of the conscious wrongdoer. In the case of other wrongdoers, the commentary to Section 51 adds:

So long as benefits wrongfully obtained have an ascertainable market value, that value is the minimum measure of the wrongdoing defendant's unjust enrichment, even if the transaction produces no ascertainable injury to the claimant and no ascertainable benefit to the defendant. Reasonable rental value or a reasonable royalty will often supply such a measure. ${ }^{103}$

The provisions of the new draft American Restatement are thus consistent with recent Canadian case law. Restitutionary remedies are clearly available in the case of innocent wrongdoing, but they focus on reversing the value transferred from the plaintiff to the wrongdoer rather than forcing the wrongdoer to disgorge its profits. The earlier American cases and their Canadian counterparts, which award the net proceeds of production to the lessor in cases of good faith trespass, are anomalous and, as Canadian courts have suggested, should not be followed. 